Editorial

\title{
Universalism in Social Policies: A Multidimensional Concept, Policy Idea or Process
}

\author{
Monica Budowski * and Daniel Künzler \\ Department of Social Work, Social Policy and Global Development, University of Fribourg, 1700 Fribourg, Switzerland; \\ E-Mails: monica.budowski@unifr.ch (M.B.), daniel.kuenzler@unifr.ch (D.K.) \\ * Corresponding author
}

Submitted: 27 February 2020 | Published: 18 March 2020

\begin{abstract}
This issue of Social Inclusion takes the dazzling and fuzzy term 'universalism' to scrutiny. The editorial introduces different usages of the term in the academic debate. It first discusses universalism as an idea, then as a process, and finally its dimensions. The articles published in this issue are situated in the debate.
\end{abstract}

\section{Keywords}

de-universalization; liberal welfare regimes; Nordic welfare states; social policy; universalization; universalism; varieties of universalism

\section{Issue}

This editorial is part of the issue “'Universalism' or 'Universalisms' in Social Policies?” edited by Monica Budowski (University of Fribourg, Switzerland) and Daniel Künzler (University of Fribourg, Switzerland).

(C) 2020 by the authors; licensee Cogitatio (Lisbon, Portugal). This article is licensed under a Creative Commons Attribution 4.0 International License (CC BY).

\section{Introduction}

This issue of Social Inclusion takes the dazzling and fuzzy term 'universalism' to scrutiny. There is no authoritarian definition and we do not attempt to present one: there are "varieties of universalism" (Anttonen \& Sipilä, 2014, p. 3) or universalisms. We introduce universalism as an idea, a process, and in its dimensions. The idea is generally discussed on the national and global level, and processes and dimensions generally on the national level or the level of single programs or policies. However, it is also important to look at the intersection of policies (see, in this issue, Tschanz \& Powell, 2020).

\section{Universalism as a Socio-Political Idea}

Sometimes the term universalism describes a sociopolitical idea that informs social policy goals. The Sustainable Development Goals (SDGs) explicitly refer to this idea (United Nations, 2015) in the field of social policies, for instance, by aiming to achieve universal health coverage by 2030 . Other universal SDGs do not explicitly use the term, e.g., the goal of eradicating extreme poverty for all people everywhere or the goal of ensuring that all girls and boys complete free, equitable and quality primary and secondary education. The World Social Protection Report (International Labour Office, 2017, p. xxix) describes another SDG-the implementation of social protection floors-as a "commitment to universalism." However, as is the case for other social policy concepts, the term universalism is popular in the international debate because it is used in a diffuse way and therefore adaptable to diverse policy goals (Palier, 2008; in this issue see also Leisering, 2020). Sometimes, universalism refers to a key normative idea behind specific national welfare systems, e.g., in what is discussed as Nordic welfare states (Goul Andersen, 2012; Stefánsson, 2012; in this issue see also Blomqvist \& Palme, 2020; Mehrara, 2020; Saikkonen \& Ylikänno, 2020). However, the term universalism was only used quite late (in the 1980s) to describe Nordic welfare states that were much older (Stefánsson, 2012). This idea of universalism was inspired by post-World War II British social policies-flat-rate pensions and health care services- 
that were designed to include the entire population. The idea of universalism thus emerged in a liberal welfare regime and referred to specific social policies (on liberal welfare regimes see, in this issue, Béland, Marchildon, \& Prince, 2020; Tschanz \& Powell, 2020).

\section{Universalization as a Process}

The post-World War II period was-broadly speakingcharacterized by a "quest for universality" in social policies:

There is a movement...towards including additional classes of the population, covering a wider range of contingencies, providing benefits more nearly adequate to needs and removing anomalies among them, loosening the tie between benefit right and contribution payment, and, in general, unifying the finance and administration of branches hitherto separate. (International Labour Office, as cited in Briggs, 1961, p. 224)

This process of universalization included social security (devised early on in the 20th century) for well-known contingencies such as old age, unemployment, disability or employment injuries that spread through most of the Global North and parts of the Global South, but were often limited to formal sector employment (again see Béland et al., 2020, for the notion of universalization). However, from the 1970s onwards, many countries in the Global North and the Global South started to reverse universalization or de-universalize at varying moments and to varied extents (Goul Andersen, 2012). Sometimes, basic features of social policies were redesigned, e.g., by fundamentally changing the financing of social policies or by introducing targeted benefits (see Mkandawire, 2005). While international organizations such as the International Monetary Fund or the World Bank pressured for structural adjustments in terms of deuniversalization, some domestic actors were also in favor of such policies. Sometimes, universal social policy programs were modified by "incremental tinkering", i.e., "numerous small manipulations in programme eligibility, decentralization of administrative responsibility, a shift from passive to active unemployment measures" (Cox, 1998, p. 2). This was justified with the argument that it strengthens universal policies in the long term. However, it might-when cumulated-weaken universalism. In recent years, several authors have observed a wave of universalization in the Global South anew (e.g., Martínez Franzoni \& Sánchez-Ancochea, 2016; see also Leisering, 2020; Öktem, 2020). These processes of universalization were not necessarily driven by the idea of universalism. However, here again, terms such as universalization and de-universalization are misleading or fuzzy as they refer to a variety of developments (for some examples see Blomqvist \& Palme, 2020; Rosenstein \& Bonvin, 2020).

\section{Dimensions of Universalism}

To analyze these developments more precisely, several dimensions of universalism can be differentiated (Goul Andersen, 2012; see Blomqvist \& Palme, 2020). This editorial presents some dimensions discussed in the literature under different designations by grouping them (and does aim at presenting an agreed-upon list of dimensions). It is important to bear in mind that applying the multidimensional term universalism to social services differs from applying it to transfers (Anttonen \& Sipilä, 2014, p. 5).

A first dimension refers to the question who is included in a social policy. Coverage of transfers or access to social services are notions that refer to this dimension. Regarding social services (e.g., health care and education), equal access is also related to the geographical distribution of facilities. In contrast to education, where access is generally a legal obligation and right, health care services are required to be accessible to those in need of such services. Universal uptake therefore does not mean the same in the fields of health care, education and transfers. Generally, legal entitlement or institutional practice are described as universal when the large majority of the population is included (Anttonen \& Sipilä, 2014, p. 6). Social services such as health care and education were inclusive in the Global North, and education became mandatory before the term universal was broadly used. Universalism referring to coverage only is criticized and considered to be a minimal form of universalism (Martínez Franzoni \& Sánchez-Ancochea, 2016 , p. 28). Strictly speaking, there is no universal entitlement in most social policies as they require citizenship or residence (Künzler \& Nollert, 2017). The universal nature of citizenship-based social policies is frequently taken for granted in some articles of this issue and more broadly in the literature (see, e.g., Anttonen \& Sipilä, 2014 , p. 5). However, citizenship- or residency-based policies are not available to denizens such as refugees, asylum seekers, stateless people, undocumented migrants or people born in a country yet without a birth certificate to prove citizenship or residence. Are citizenship-based social policies really universal or should they rather be described as based on a categorical entitlement or being group-universal (Stefánsson, 2012, p. 47)? Age-based or gender-based entitlement is another form of categorical entitlement. Selective entitlement also comes into play when members of a category must fulfil certain criteria to be entitled, e.g., have an income below a defined threshold. Categorical entitlements and meanstested programs are more expensive to administer, entail inclusion and exclusion errors, and require a certain level of state capacity (Mkandawire, 2005). Furthermore, they bear the potential to create stigma and be less redistributive than universal programs (Korpi \& Palme, 1998; Martínez Franzoni \& Sánchez-Ancochea, 2016).

A second dimension of universalism refers to the providers. Martínez Franzoni and Sánchez-Ancochea 
(2016) emphasize the quality of services. If quality of health care or educational services throughout a country or in disadvantaged regions is low, these services might not be used, as people seek alternatives or opt out. Therefore, the authors maintain that even when coverage and access rates are high, universalism cannot be considered strong when quality of the services is low. Some scholars argue that in order to qualify as universal, services must be provided by the government (see Blomqvist \& Palme, 2020). Others insist that governments must define and supervise standards to be respected by all providers, but that it does not matter whether providers are public, private for profit or nonprofit (see in this issue the discussion of universality by Béland et al., 2020; see also Budowski, 2020). Besides questions of quality, providers also matter when implementing services and transfers (see Mehrara, 2020; Rosenstein \& Bonvin 2020; Tschanz \& Powell, 2020), as, for example, the selection of 'legitimate beneficiaries' may have exclusionary effects.

Policy outcomes are a third dimension of universalism. In increasingly diverse societies, universalism requires "some degree of particularism or positive selectivism" (Anttonen \& Sipilä, 2014, p. 14) to ensure that groups with specific needs are "on an equal footing with the rest of the citizenry" (Stefánsson, 2012, p. 62; see also Mehrara, 2020; Tschanz \& Powell, 2020).

Financing of social services and transfers is a fourth dimension of universalism frequently mentioned. Some scholars consider indirect financing to be universalpreferably through progressive taxing and not through contributions or direct payment at time of need (Goul Andersen, 2012; see Blomqvist \& Palme, 2020). Other scholars consider financing of a service universal when direct payment at time of need is not required and does not lead to poverty therewith allowing for further modes of payments such as compulsory insurance contributions (payroll taxes), voluntary insurance premiums, or foreign assistance to complement taxes (WHO, 2010).

Adequacy of benefits is a fifth dimension mainly discussed in the Global North (Anttonen \& Sipilä, 2014, pp. 4-5; Goul Andersen, 2012, pp. 164-165). Adequate benefits assure a decent-not minimal-standard of living and are broadly supported by citizens; adequate benefits reduce the tendency of richer groups to choose to complement or substitute benefits with private solutions. While adequacy is considered necessary for universalism by some Northern authors (Goul Andersen, 2012, p. 166; see Blomqvist \& Palme, 2020), social protection floors mentioned above are clearly minimal (see Öktem, 2020). A "maximalist universalist approach" (Martínez Franzoni \& Sánchez-Ancochea, 2016, pp. 28-30) that includes broad coverage and access, sufficiently generous transfers for a socially acceptable living standard, and quality services furthering equality in outcomes and inclusion beyond citizenship is yet quite elusive.

\section{Acknowledgments}

The authors are listed alphabetically and contributed equally.

\section{Conflict of Interests}

The authors declare no conflict of interests.

\section{References}

Anttonen, A., \& Sipilä, J. (2014). Varieties of universalism. Draft paper prepared for the UNRISD Conference "New Directions in Social Policy: Alternatives from and for the Global South," Geneva, Switzerland. Retrieved from http://www.unrisd.org/80256B3C0 05BCCF9/(httpAuxPages)/D04EC7C33C9EC48AC125 7D0800293153/\$file/Anttonen\%20and\%20Sipila.pdf

Béland, D., Marchildon, G. P., \& Prince, M. J. (2020). Understanding universality within a liberal welfare regime: The case of universal social programs in Canada. Social Inclusion, 8(1), 124-132.

Blomqvist, P., \& Palme, J. (2020). Universalism in welfare policy: The Swedish case beyond 1990. Social Inclusion, 8(1), 114-123.

Briggs, A. (1961). The welfare state in historical perspective. European Journal of Sociology, 2(2), 221-258.

Budowski, M. (2020). Universalism in healthcare and social citizenship in Chile, Uruguay and Costa Rica. In F. Collyer \& K. Willis (Eds.), Navigating the healthcare system (pp. 15-39). London: Palgrave Macmillan.

Cox, R. H. (1998). The consequences of welfare reform: How conceptions of social rights are changing. Journal of Social Policy, 27(1), 1-16.

Goul Andersen, J. (2012). Universalization and deuniversalization of unemployment in Denmark and Sweden. In A. Anttonen, L. Häikiö, \& K. Stefánsson (Eds.), Welfare state, universalism and diversity (pp. 162-186). Cheltenham: Edward Elgar.

International Labour Office. (2017). World social protection report 2017-19: Universal social protection to achieve the Sustainable Development Goals. Geneva: ILO. Retrieved from https://www.ilo.org/wcmsp5/ groups/public/---dgreports/---dcomm/---publ/ documents/publication/wcms_604882.pdf

Korpi, W., \& Palme, J. (1998). The paradox of redistribution and strategies of equality: Welfare state institutions, inequality and poverty in the Western countries. American Sociological Review, 63(5), 661-687.

Künzler, D., \& Nollert, M. (2017). Varieties and drivers of social welfare in sub-Saharan Africa: A critical assessment of current research. socialpolicy.ch, 2017(2). http://dx.doi.org/10.18753/2297-8224-94

Leisering, L. (2020). The calls for universal social protection by international organizations: Constructing a new global consensus. Social Inclusion, 8(1), 90-102.

Martínez Franzoni, J., \& Sánchez-Ancochea, D. (2016). The quest for universal social policy in the South. Ac- 
tors, ideas, and architectures. Cambridge: Cambridge University Press.

Mehrara, L. (2020). Seeking the ideal of universalism within Norway's social reality. Social Inclusion, 8(1), 133-144.

Mkandawire, T. (2005). Targeting and universalism in poverty reduction (Social Policy and Development Programme Paper No. 23). Geneva: United Nations Research Institute for Social Development.

Öktem, K. G. (2020). The welfare state as universal social security: A global analysis. Social Inclusion, 8(1), 103-113.

Palier, B. (2008). De l'ambiguïté en politique [Of ambiguity in policies]. In O. Giraud \& P. Warin (Eds.), Politiques publiques et démocratie [Public policies and democracy] (pp. 93-107). Paris: La Découverte.

Rosenstein, E., \& Bonvin, J.-M. (2020). Paradoxes of universalism: The case of the Swiss disability insurance. Social Inclusion, 8(1), 168-177.
Saikkonen, P., \& Ylikänno, M. (2020). Is there room for targeting within universalism? Finnish social assistance recipients as social citizens. Social Inclusion, 8(1), 145-154.

Stefánsson, K. (2012). What is in a word? Universalism, ideology and practice. In A. Anttonen, L. Häikiö, \& K. Stefánsson (Eds.), Welfare state, universalism and diversity (pp. 42-68). Cheltenham: Edward Elgar.

Tschanz, C., \& Powell, J. J. W. (2020). Competing institutional logics and paradoxical universalism: School-towork transitions of disabled youth in Switzerland and the United States. Social Inclusion, 8(1), 155-167.

United Nations. (2015). Sustainable Development Goals. United Nations. Retrieved from https:// sustainabledevelopment.un.org/\#

WHO. (2010). The world health report 2010. Health systems financing: The path to universal coverage. Geneva: World Health Organization.

\section{About the Authors}
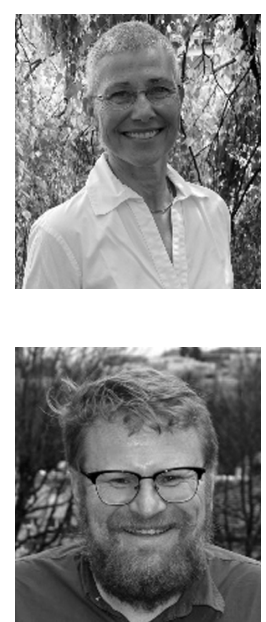

Monica Budowski is Professor of Sociology, Social Policy and Social Work at the University of Fribourg, Switzerland. Previously, Monica was Scientific Head of the Swiss Household Panel at the University of Neuchâtel and Research Fellow at the London School of Economics, Princeton University, and the Universidad de Costa Rica. She has published in the fields of social inequality, poverty, precarious prosperity, stratification, welfare, subjective well-being, quality of life, health, households, families and gender, social policy (especially in Latin America) with qualitative and quantitative methods, longitudinal analyses and often from a comparative perspective.

Daniel Künzler is Lecturer at the Department of Social Work, Social Policy and Global Development, University of Fribourg (Switzerland). He is currently working on the dynamics and politics of social policies in Kenya and colonial legacies and social policies in Middle Africa. His general research interests are social policies in sub-Saharan Africa and popular culture, with a special focus on Eastern Africa. 